\title{
Survivability of Salmonella and shiga-toxigenic Escherichia coli (STEC) 0157 in microwave heated ready-to-eat (RTE) foods
}

\author{
${ }^{1 * N e w, ~ C . Y ., ~}{ }^{2}$ Mohammed, A.S., ${ }^{3}$ Abdul Rahman, R. and ${ }^{1,4}$ Son, R. \\ ${ }^{1}$ Department of Food Science, Faculty of Food Science and Technology, Universiti Putra Malaysia, \\ Selangor, Malaysia \\ ${ }^{2}$ Department of Microbiology and Biotechnology, Faculty of Science, Federal University Dutse, Jigawa \\ State, Nigeria \\ ${ }^{3}$ Department of Food Technology, Faculty of Food Science and Technology, Universiti Putra Malaysia, \\ Selangor, Malaysia \\ ${ }^{4}$ Food Safety and Food Integrity, Institute of Tropical Agriculture and Food Security, Universiti Putra \\ Malaysia, Selangor, Malaysia
}

\author{
Article history: \\ Received: 11 March 2018 \\ Received in revised form: 14 \\ April 2018 \\ Accepted: 28 April 2018 \\ Available Online: 9 May \\ 2018
}

\section{Keywords:}

Microwave heating,

Survivability,

Risk,

Salmonella,

STEC O157

\section{DOI:}

https://doi.org/10.26656/fr.2017.2(4).E01

\begin{abstract}
The safety level of microwaved foods remains at vague as this subject was less addressed scientifically. A study was initiated to address the matter by investigating on the survivability of Salmonella and Shiga-toxigenic Escherichia coli (STEC) O157 in microwave heated ready-to-eat (RTE) foods using the Most Probable Number coupled Polymerase Chain Reaction (MPN-PCR) technique. A total of 329 samples of various ready-to-eat (RTE) convenience meals were collected around Wilayah Persekutuan Kuala Lumpur and Selangor regions. Salmonella was positively identified in 66 samples $(20.1 \%$, $<3.0-11000 \mathrm{MPN} / \mathrm{g})$ while 86 samples $(26.1 \%,<3.0->11000 \mathrm{MPN} / \mathrm{g})$ were positive for E. coli. Out of the 66 positive Salmonella samples, $S$. enterica serovar Typhimurium was identified in 6 samples $(1.8 \%,<3.0-62.0 \mathrm{MPN} / \mathrm{g})$ and $S$. enterica serovar Enteritidis was identified in 13 samples $(4.0 \%,<3.0-270 \mathrm{MPN} / \mathrm{g})$. On the other hand, 17 out of the 86 positive E. coli samples were identified as positive STEC O157 (5.2\%, 3.0-930 MPN/g). The results signified the high possibility of the pathogens' survival in RTE foods due to uneven heat distribution, resulting in the presence of cold spots which supports the growth of the pathogens, as well as the microwave reheating time and lack consumers' knowledge on the microwave oven. The risk of contracting foodborne illness from the consumption of survived pathogens in microwave heated RTE food was estimated using the @RISK ${ }^{\circledR}$ Version 7.5 (Palisade, USA). The outcome indicated a moderate to high rate of foodborne illness incidence which indicated the need to create the awareness on the safety of microwaved foods and provide proper microwaving guidelines to mitigate the risk.
\end{abstract}

\section{Introduction}

Upon the discovery that microwaves can cook food faster than conventional ovens by Dr. Percy LeBaron Spencer while researching on magnetron, it was a breakthrough in food technology and currently, microwave oven is an irreplaceable electronic appliance in every household due to its ability to achieve high heating rates, significant reduction in cooking time, more uniform heating, safe handling, ease of operation; low maintenance and energy efficiency (Zhang et al., 2006; Salazar-Gonzalez et al., 2012; Puligundia et al., 2013). Microwaves are wavelengths of electromagnetic radiation between 1 to $0.001 \mathrm{~m}$ (Decareau, 1985), in between infrared and radio frequency. The frequencies ranged from $300 \mathrm{MHz}$ to $300 \mathrm{GHz} .915 \mathrm{MHz}$ and 2.45 $\mathrm{GHz}$ are the domestic frequencies used for industrial, scientific and medical application (Meredith, 1998; Hoogenboom et al., 2009).

Microwave heating is known as dielectric heating. Microwaves generate heat from the transformation of alternating electromagnetic field energy into thermal energy by affecting the polar molecules of a material, particularly polar water molecules and charged ions in food (Vadivambal and Jayas, 2010). Heat is being 
created internally by the polar molecules after microwave absorption to generate a volumetric heating effect, leading to faster heating rate (Vadivambal and Jayas, 2010), which is not achievable by any other conventional means (Fu, 2006). Conventional heating occurs by convection whereby heat is transferred from the surface to the interior of the food and requires more time. The absorption of the microwaves by the polar molecules will cause the polar molecules to orientate themselves according to the electromagnetic radiation, leading to the breaking of hydrogen bonds associated to the water molecules and generation of molecular friction within. Moreover, ions of dissolved salts in food will migrate towards the oppositely charged regions during the interaction with the electromagnetic field and produces heat (Decareau and Peterson, 1986; Oliviera and Franca, 2002). With millions of molecules in food, the reaction occurs a million times and rapidly generating heat.

However, the efficient microwave heating has some major drawbacks. Researchers Ho and Yam (1992) and Campanone and Zaritzky (2005) reported hot spot zones existence in food depending on geometry which suggested a temperature distribution fluctuation. This was first confirmed by Fakhouri and Ramaswamy (1993) and reported non-uniform temperature distribution in microwave heated commercially refrigerated and frozen foods. Subsequent reports on non-uniform temperature distribution studied by other researchers surfaced which prominently confirmed the non-uniform temperature distribution of the microwave heating affected by the thickness and dielectric properties of the food (Fakhouri and Ramaswamy, 1993; Mullin and Bows, 1993; Ryynanen and Ohlsson, 1996; Manickavasagan et al., 2006; Geedipalli et al., 2007; Gunasekaran and Yang, 2007). This led to other rising problems such as poor end quality, microbial safety concerns and overheating (Vadivambal and Jayas, 2010).

Microbial safety concerns in microwave heated foods were given less attention as there were few to no proper guidelines established. Despite that, outbreaks concerning microwave heated foods had been surfacing since 1992 till recently in 2013. In 1992, microwave heated rice salad serving as a buffet meal was reported to be contaminated to cause an outbreak of $S$. enterica serovar Enteritidis by Evans et al. (1995) who reported that the source of contamination was from the food handlers. In 1994, S. enterica serovar Typhimurium caused an outbreak after the consumption of contaminated leftover roast pork which was heated using the microwave oven (Gessner and Beller, 1994). Since then, several outbreaks surfaced following the events mostly related to microwaveable frozen food products associated with Salmonella. Smith et al. (2008) reported a salmonellosis outbreak from 1998 to 2006 in Minnesota due to the consumption of microwaved stuffed chicken products. In 2007, Salmonella serotype I contamination in microwaved frozen pot pies caused a multistate outbreak in the USA having over 401 outbreak cases (Meyer et al., 2008). In 2010, cheesy chicken and rice frozen meals contaminated with $S$. enterica serotype Chester cooked using the microwave oven had caused a multistate outbreak in the USA (Rounds et al., 2013). In 2013, an outbreak of Escherichia coli O121 associated with the consumption of microwaved heated Farm Rich products was reported that had caused thirty-five people sickened in nineteen states in the U.S (Larsen, 2013).

Based on the reported outbreaks, there is an arising microbiological risk in microwave heated foods. As the microwave oven is a commonly used electronic appliance in every household, there is a need to address the microbiological concerns. This had challenged us to report on the survivability of pathogens, particularly Salmonella and Shiga-toxigenic Escherichia coli (STEC) O157 in microwave heated ready-to-eat (RTE) food. The causes of most reported outbreaks were due to consumers' misconception on the microwaves in food processing and the lack of knowledge on the microwave oven. Through this report, it is hoped that an awareness regarding microwave heating can be elevated. The risk factors associated with the survivability of the pathogens will also be addressed in this report.

\section{Materials and methods}

\subsection{Sampling}

The sample size was estimated based on the formula (Daniel, 1999).

$$
\mathrm{n}=\frac{\mathrm{Z}^{2} \mathrm{P}(1-\mathrm{P})}{\mathrm{d}^{2}}
$$

where $\mathrm{n}=$ sample size; $\mathrm{Z}=\mathrm{Z}$ statistic for a level of confidence (1.96 at $95 \%$ confidence interval); $P=$ expected prevalence or proportion; and $d=$ precision. As there was no available prevalence data recorded for Salmonella and E. coli, a pilot test study (30 samples) was applied to obtain a crude $P$ value and $d$ value (Daniel, 1999; Pourhoseingholi et al., 2013). The outcome of the pilot test study resulted in a prevalence of 0.067 and 0.3 for Salmonella and E. coli respectively. According to Naing et al. (2006), the appropriate $d$ value is determined based on the prevalence. If the prevalence is below 0.1, it is recommended that $d$ is half of $P$. Hence, the estimated sample size for Salmonella was 215 using Equation (1). On the other hand, the estimated sample size for E. coli was 323 as the $d$ value is recommended to be set at 0.05 if the prevalence is between 0.1 and 0.9 (Naing et al., 2006). 
A total of 329 samples were analysed and the types of sample and sample size were tabulated in Table 4. Based on the sample size calculation, it was decided that the number of samples collected should be based on the estimated sample size of $E$. coli as the study was carried out concurrently for both foodborne pathogens. Additional samples were collected if possible errors occur. RTE foods were purchased from convenient stores around Wilayah Persekutuan Kuala Lumpur and Selangor region. The RTE foods purchased are either those that are ready packed in microwavable containers or packed in its original packaging. Samples that were packed in its original packaging when purchased were aseptically transferred into UV sterilized microwavable containers $(172 \times 120 \times 57 \mathrm{~mm})$. Samples were then subjected to microwave heating using a domestic microwave oven [Elba, Malaysia] at $700 \mathrm{~W}, 2.45 \mathrm{GHz}$ for $1 \mathrm{~min}$.

According to New, Thung, Premarathne et al. (2017), most of the respondents that participated in a microwave oven safety survey indicated that they reheated their food for $1 \mathrm{~min}$. Hence, the microwave heating time was selected based on the respondents' preference. After microwave heating, samples were allowed to stand for 5 mins, following the recommended procedures of the Microwave Oven Food Safety by the United States Food and Drug Analysis (US FDA)/Food Safety Inspection Services (FSIS) (2011). Immediately after standing, the center temperature of the samples was recorded using a temperature probe. Samples were mixed to homogenize before aseptically weighed $10 \mathrm{~g}$ of the portion into a stomacher bag. Then, $90 \mathrm{~mL}$ of Buffered Peptone Water (BPW) [Merck, Germany] was added and the mixture was plunged for $1 \mathrm{~min}$. The stomacher bag containing the homogenized mixture was then loosely sealed and incubated at $37^{\circ} \mathrm{C}$ for $6 \mathrm{~h}$.

\subsection{Most Probable Number-Polymerase Chain Reaction $(M P N-P C R)$}

The $6 \mathrm{~h}$ incubated homogenized mixture was then subjected to three-tube MPN method according to United States Food and Drug Administration Bacteriological Analytical Method (BAM) by Blodgett (2010) with modification. Briefly, the homogenized mixture was diluted ten-fold for three consecutive times. For each dilution, $1 \mathrm{~mL}$ was aliquoted into three tubes of $9 \mathrm{~mL}$ BPW (MPN tubes). The MPN tubes were then incubated at $37^{\circ} \mathrm{C}$ for 18 to $24 \mathrm{~h}$. Turbid MPN tubes indicated growth of the microorganisms and were proceeded to the isolation of microorganisms. All MPN tubes were subjected to DNA template preparation for PCR analysis.

\subsection{DNA template preparation}

DNA template preparation was performed using the boiling method with modifications as described by Tang et al. (2009). Briefly, $1 \mathrm{~mL}$ were transferred from the MPN tubes into $1.5 \mathrm{~mL}$ of microcentrifuge tubes. The microcentrifuge tubes were centrifuged at $12,000 \mathrm{rpm}$ for 3 minutes and then, had its supernatant discarded. $500 \mu 1$ of Ultra-Pure water was added to re-suspend the pellet. The tubes were then vortexed vigorously to dissolve the pellet and boiled for 10 minutes at $100 \pm 2{ }^{\circ} \mathrm{C}$ using a dry cell bath. Immediately, after boiling, the tubes were transferred to $-20^{\circ} \mathrm{C}$ freezer until further use.

\subsection{PCR analysis}

DNA templates were thawed and centrifuged for short spin (approximately 30s) at 12,000 rpm before subject to PCR analysis. The same DNA template was used for the triplex PCR analysis for Salmonella and hexaplex PCR analysis for E. coli O157: H7.

Triplex PCR analysis for Salmonella was carried out by mixing $5 \mu \mathrm{l}$ of DNA template with the following concentrations of PCR reagents: 1.5X of PCR Buffer, 2.0 $\mathrm{Mm}$ of $\mathrm{MgCl}_{2}, 0.2 \mathrm{mM}$ of dNTP mix; $0.2 \mu \mathrm{M}$ of $E N T$ primers; $0.1 \mu \mathrm{M}$ of each Typh primers and ompC primers; and $1.5 \mathrm{U}$ of Taq polymerase. The final volume of $25 \mu \mathrm{l}$ was achieved by adding sterile distilled water to top up. The PCR conditions for the Triplex PCR analysis for Salmonella was optimized following the steps: predenaturation at $95^{\circ} \mathrm{C}$ for 3 minutes; 35 cycles of denaturation at $95^{\circ} \mathrm{C}$ for 1 minute, annealing at $56^{\circ} \mathrm{C}$ for 1 minute, extension at $72^{\circ} \mathrm{C}$ for 1 minute; and final extension at $72^{\circ} \mathrm{C}$ for 7 minutes before holding at $4^{\circ} \mathrm{C}$.

Hexaplex PCR analysis for E. coli O157: H7 was carried out by mixing $2 \mu \mathrm{l}$ of DNA template with the following concentrations of PCR reagents: 1.5X PCR Buffer, $4.0 \mathrm{Mm}$ of $\mathrm{MgCl}_{2}, 0.4 \mathrm{mM}$ of dNTP mix; $0.2 \mu \mathrm{M}$ of primers; and $2.0 \mathrm{U}$ of Taq polymerase. The PCR tubes were subjected to pre-denaturation at $94^{\circ} \mathrm{C}$ for 5 minutes, 35 cycles of denaturation at $94^{\circ} \mathrm{C}$ for 30 seconds, annealing at $57^{\circ} \mathrm{C}$ for 30 seconds, extension at $72^{\circ} \mathrm{C}$ for 1 minute and 15 seconds; and final extension at $72^{\circ} \mathrm{C}$ for 7 minutes before holding at $4^{\circ} \mathrm{C}$.

The primers used in the PCR analysis were as shown in Table 1 and Table 2 for Salmonella and E. coli O157: $\mathrm{H} 7$ respectively. All PCR reagents were purchased from Promega (USA) except for the primers that were synthesized by Sigma-Aldrich, Malaysia. Amplicons were separated via $1.25 \%$ agarose gel electrophoresis stained with $0.5 \mu \mathrm{g} / \mathrm{mL}$ of Ethidium Bromide (EtBr) at $60 \mathrm{~V}$ for 1 hour and 15 minutes for E. coli O157: H7 while at $90 \mathrm{~V}$ for 30 minutes for Salmonella. Visualization of the gel was performed under Gel Documentation System (Syngene, USA). 
Table 1. Primer sequence used for Salmonella detection

\begin{tabular}{cclcc}
\hline Pathogen & Primers & \multicolumn{1}{c}{ Primer Sequence 5' $\rightarrow 3$} & Amplicon & References \\
\hline \multirow{2}{*}{ Salmonella genus } & ompC $-\mathrm{F}$ & ATC GCT GAC TTA TGC AAT CG & ompC & de Freitas et \\
& ompC $-\mathrm{R}$ & CGG GTT GCG TTA TAG GTC TG & $(204 \mathrm{bp})$ & al. $(2010)$ \\
\hline S. enterica serovar & ENT $-\mathrm{F}$ & AAA TGT GTT TTA TCT GAT GCA AGA GG & Sdfl & Stegniy et al. \\
Enteritidis & ENT $-\mathrm{R}$ & GTT CGT TCT TCT GGT ACT TAC GAT GAC & $(299 \mathrm{bp})$ & $(2014)$ \\
\hline S. enterica serovar & Typh $-\mathrm{F}$ & TTG TTC ACT TTT TAC CCC TGA A & Spy & de Freitas et \\
Typhimurium & Typh $-\mathrm{R}$ & CCC TGA CAG CCG TTA GAT ATT & $(401 \mathrm{bp})$ & al. $(2010)$ \\
\hline
\end{tabular}

Table 2. Primer sequence used for Escherichia coli O157:H7 detection

\begin{tabular}{|c|c|c|c|c|}
\hline Pathogen & Primers & Primer Sequence $5{ }^{\prime} \rightarrow 3^{\prime}$ & Amplicon & References \\
\hline \multirow{12}{*}{$\begin{array}{l}\text { Escherichia } \\
\text { coli } \mathrm{O} 157: \mathrm{H} 7\end{array}$} & $f l i C-\mathrm{F}$ & AGC TGC AAC GGT AAG TGA TTT & fliC & Wang et al. (2000) as \\
\hline & $f l i C-\mathrm{R}$ & GGC AGC AAG CGG GTT GGT C & (949 bp) & cited in Bai et al. (2010) \\
\hline & stxl-F & TGT CGC ATA GTG GAA CCT CA & & \multirow{2}{*}{ Bai et al. (2010) } \\
\hline & stx1-R & TGC GCA CTG AGA AGA AGA GA & $(655 \mathrm{bp})$ & \\
\hline & ECA75-F & GGA AGA AGC TTG CTT CTT TGC TGA C & \multirow{2}{*}{$\begin{array}{l}\text { 16s rRNA } \\
(544 \mathrm{bp})\end{array}$} & \multirow{2}{*}{ Sabat et al. (2000) } \\
\hline & ECR619-R & AGC CCG GGG ATT TCA CAT CTG ACT TA & & \\
\hline & $s t x 2-\mathrm{F}$ & CCA TGA CAA CGG ACA GCA GTT & \multirow{2}{*}{$\begin{array}{c}\text { stx2 } \\
(477 \mathrm{bp})\end{array}$} & \multirow{2}{*}{$\begin{array}{l}\text { Fagan et al. (1999) and } \\
\text { Bai et al. }(2010)\end{array}$} \\
\hline & stx $2-\mathrm{R}$ & TGT CGC CAG TTA TCT GAC ATT C & & \\
\hline & eae - F & CAT TAT GGA ACG GCA GAG GT & \multirow{2}{*}{$\begin{array}{c}\text { eae } \\
\text { (375 bp) }\end{array}$} & \multirow{2}{*}{ Bai et al. (2010) } \\
\hline & $e a e-\mathrm{R}$ & ACG GAT ATC GAA GCC ATT TG & & \\
\hline & $r f b E-\mathrm{F}$ & CAG GTG AAG GTG GAA TGG TTG TC & \multirow{2}{*}{$\begin{array}{c}r f b E \\
(296 \mathrm{bp})\end{array}$} & \multirow{2}{*}{ Bertrand and Roig (2007) } \\
\hline & $r f b E-\mathrm{R}$ & TTA GAA TTG AGA CCA TCC AAT AAG & & \\
\hline
\end{tabular}

\subsection{Risk assessment}

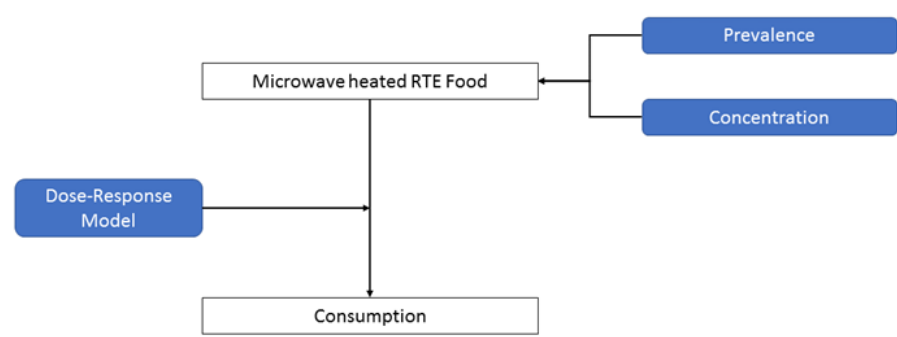

Figure 1. The risk assessment model to simulate the risk of consumption of survived pathogens in microwaved heated RTE food.

The exposure pathway on the direct consumption of the RTE food with possible contamination of survived pathogens during microwave heating was modelled as shown in Figure 1. It was assumed that consumers are exposed to the survived pathogens through the consumption of the RTE food. Separate simulations were performed using @ RISK ${ }^{\circledR}$ Version 7.5 (Palisade, USA) based on 100,000 iterations to estimate the probability of illness per serving of each pathogen for each type of sample of RTE food. Information on the serving size of the food was obtained from the report on the Food Consumption Statistics by the Ministry of Health, Malaysia (2013). Beta-Poisson model and exponential model were used for Salmonella and STEC O157 respectively for the dose-response model. The alpha and beta values of the Beta-Poisson model for Salmonella was adopted from the risk assessment study on
Salmonella in Eggs and Broiler Chickens by the World Health Organization (WHO) (2002) while the exponential value was obtained from the exponential model for STEC O157 was adopted from Cornick and Helgerson (2004) whom studied on the dose of Enterohaemorrhagic E. coli (EHEC) O157: H7 in pigs. Parameters and distributions used in the simulation model were described in Table 3 .

Table 3. Description of parameters and input distributions of the risk assessment model

\begin{tabular}{|c|c|c|}
\hline Parameter & $\begin{array}{c}\text { Description of } \\
\text { Parameter }\end{array}$ & Input Distribution \\
\hline$P_{x}$ & Prevalence & $\operatorname{Beta}(s+1, n-s+1)^{a}$ \\
\hline $\mathrm{C}_{\mathrm{x}}$ & $\begin{array}{c}\text { Contamination } \\
\text { level of } \\
\text { pathogens }\end{array}$ & Pert (Min, Med, Max) ${ }^{b}$ \\
\hline $\mathrm{S}_{\mathrm{x}}$ & $\begin{array}{l}\text { Serving } \\
\text { Amount }\end{array}$ & Normal $(\mu \pm \sigma)^{\mathrm{c}}$ \\
\hline $\mathrm{C}_{\mathrm{e}}$ & $\begin{array}{l}\text { Customer } \\
\text { exposure }\end{array}$ & Antilog $\left(\mathrm{C}_{\mathrm{x}} * \mathrm{~S}_{\mathrm{x}}\right)$ \\
\hline $\mathrm{P}_{\text {ill }}$ & $\begin{array}{l}\text { Probability of } \\
\text { illness }\end{array}$ & $\begin{array}{c}\text { Salmonella: } \\
\mathrm{P}_{\mathrm{ill}}=1-\left(1+\mathrm{C}_{\mathrm{e}} / 2890\right)^{\wedge}(-0.313) \\
\text { STEC O157: }^{\wedge} \\
\mathrm{P}_{\mathrm{ill}}=1-e^{\wedge}-\left[\mathrm{C}_{\mathrm{e}} * 0.000218\right]\end{array}$ \\
\hline
\end{tabular}

${ }^{\mathrm{a}} \mathrm{s}=$ total number of positive samples; $\mathrm{n}=$ total number of samples

${ }^{\mathrm{b}}$ Min, Med, Max values are in $\log 10$

${ }^{c} \mu=$ mean value in $\log 10, \sigma=$ standard deviation value in $\log$ 10

d values were obtained from the Ministry of Health, Malaysia (2013) 

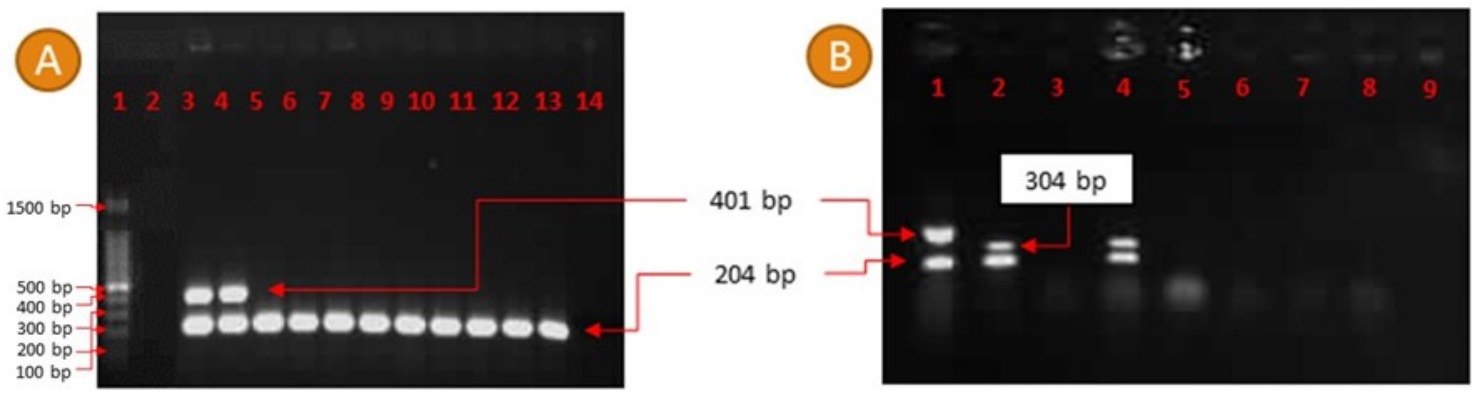

Figure 2. PCR amplification product of Salmonella (A) Lane 1: 100 bp DNA Ladder (Promega, USA); Lane 2: Negative control; Lane 3 - 14: Samples. (B) Lane 1: Positive Control for S. enterica serovar Typhimurium with molecule size markers (Spy gene at $401 \mathrm{bp}$ and $о \mathrm{mpC}$ gene at $204 \mathrm{bp}$ ); Lane 2: Positive control for S. enterica serovar Enteritidis (Sdf1 gene at $304 \mathrm{bp}$ and ompC gene at 204 bp); Lane 3: Negative Control; Lane 4 - 9: Samples

\section{Results and discussion}

Salmonella and E. coli were detected in RTE food samples implied that the pathogens survived the oneminute microwave heating. Salmonella was detected in 66 out of 329 samples $(20.1 \%)$ with a density of $<3.0-$ $11000 \mathrm{MPN} / \mathrm{g}$, through the identification of the amplification of specific ompC gene of Salmonella at $204 \mathrm{bp}$ that encodes for the protein $\mathrm{C}$ involved in the invasion of epithelial cells (de Freitas et al., 2010). Out of the 66 samples, 6 samples $(1.8 \%)$ were identified as positive for $S$. enterica serovar Typhimurium through the presence of the Spy gene amplicons at $401 \mathrm{bp}$ that encodes a specific periplasmatic protein for Typhimurium serotype while 13 samples $(4.0 \%)$ were identified as positive for $S$. enterica serovar Enteritidis. The fragment of $S d f 1$ gene encoding the chromosomal region related to invasiveness and infection of poultry and eggs was used for the identification of the Enteritidis serotype and when amplified, produced 299 bp fragments (de Freitas et al., 2010). Figure 2 shows the amplicons produced through the triplex PCR analysis for Salmonella. The density for $S$. enterica serovar Typhimurium and $S$. enterica serovar Enteritidis in RTE foods was $<3.0-62.0 \mathrm{MPN} / \mathrm{g}$ and $<3.0-270.0 \mathrm{MPN} / \mathrm{g}$ respectively.

In contrast, E. coli was highly detectable in RTE foods compared to Salmonella with 86 positive samples $(26.1 \%)$. This was identified through the presence of the hypervariable regions of $E$. coli $16 \mathrm{~s}$ rRNA fragments at 544 bp (Sabat et al., 2000) which was the internal standard used in the multiplex PCR. E. coli O157: H7 is the common causative agent of diarrheal illness of the STEC group and it is responsible for many outbreaks, having the virulence genes, typically stxl (Shiga toxin 1), stx2 (Shiga toxin 2), eae (intimin), $r f b E$ (O157 antigen) and $f l i C$ (flagellar antigen) in its DNA (Bai et al., 2010). Targeting the virulence genes in multiplex PCR will not be sufficient as there are other bacteria like Shigella dsyentria that produces Shiga toxin, similar to STEC. Hence, the presence of E. coli 16s rRNA gene as the $E$. coli internal standard will validate the multiplex
PCR for identification of STEC O157: H7. There were 17 samples (5.2\%) positively identified as STEC O157 with the density of $<3.0-930 \mathrm{MPN} / \mathrm{g}$ via the amplicons of stx 1 at $655 \mathrm{bp}$, stx 2 at $477 \mathrm{bp}$, eae at $375 \mathrm{bp}$, and $r f b E$ at $296 \mathrm{bp}$ (Figure 3). To identify the pathogen as STEC, either the stx 1 or the stx 2 gene amplicons should be present. The confirmation of $\mathrm{O} 157$ and $\mathrm{H} 7$ was through the amplicons of the $r f b E$ gene and $f l i C$ gene. It was noted that all the identified STEC O157 produced the $r f b E$ gene amplicon but did not produce the $f l i C$ gene amplicon. Hence, only STEC O157 was identified from the RTE foods.

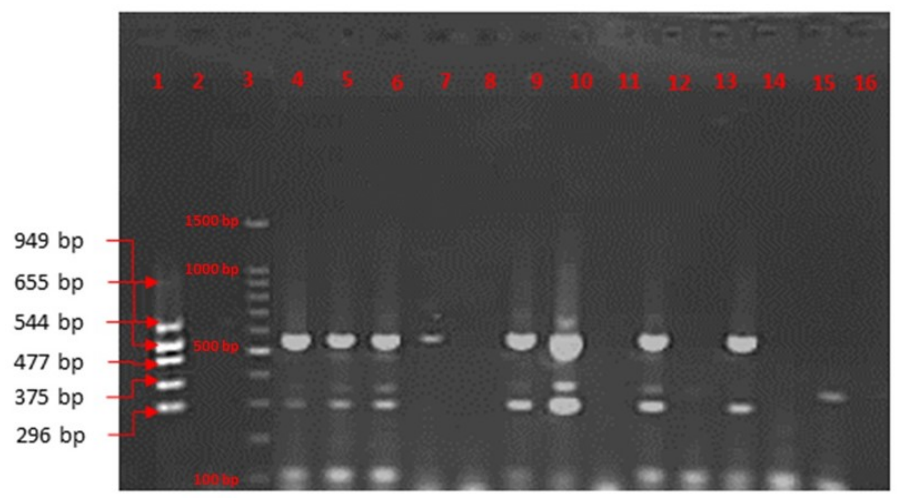

Figure 3. PCR amplification product of E. coli O157: H7. Lane 1: Positive control with molecule size markers (fliC gene at 949 bp; stx 1 gene at 655 bp; 16s rRNA E. coli gene at 544 bp; stx2 gene at $477 \mathrm{bp}$; eae gene at $375 \mathrm{bp}$ and $r f b E$ gene at 296 bp); Lane 2: Negative control; Lane 3: 100 bp DNA Ladder (Promega, USA); Lane 4 - 16: Samples

The total number of positive detection of Salmonella and STEC O157 with the respective MPN/g densities in accordance with the types of samples is tabulated in Table 4. The distribution of the survived pathogens in food samples as shown in Table 4 was presumably viewed as initial contamination by the food handlers as there was no common type of sample that contained a specific survived pathogen. Cross-contamination in food occurs through various ways and sources, which the cause is difficult to be identifiable due to the complexity of the food processes. The most probable transmission of occurrence could be through food handlers, the major 
Table 4. Number of positive samples and concentration of Salmonella and STEC detected in accordance with the type of sample

\begin{tabular}{|c|c|c|c|c|c|c|}
\hline \multirow[b]{2}{*}{ Sample } & \multirow{2}{*}{$\begin{array}{c}\text { Sample's } \\
\text { Weight } \\
\text { Range (g) }\end{array}$} & \multirow{2}{*}{$\begin{array}{c}\text { Total No. of } \\
\text { Samples } \\
\text { n (\%) }\end{array}$} & \multicolumn{2}{|c|}{ Salmonella } & \multicolumn{2}{|c|}{ STEC O157 } \\
\hline & & & $\begin{array}{c}\text { No. Positive } \\
\text { Samples n (\%) }\end{array}$ & $\mathrm{MPN} / \mathrm{g}$ & $\begin{array}{c}\text { No. Positive } \\
\text { Samples n (\%) }\end{array}$ & $\mathrm{MPN} / \mathrm{g}$ \\
\hline $\begin{array}{l}\text { Nasi Lemak (Coconut } \\
\text { Rice) }\end{array}$ & $200-250$ & $77(23 \%)$ & $11(14.3 \%)$ & $<3.0-210.0$ & $6(35.3 \%)$ & $<3.0-290.0$ \\
\hline Fried Noodles & $100-150$ & $82(25 \%)$ & $22(26.8 \%)$ & $<3.0-1500.0$ & $5(29.4 \%)$ & $<3.0-930.0$ \\
\hline Fried Rice & $200-250$ & $76(23 \%)$ & $17(22.4 \%)$ & $<3.0-11000.0$ & $4(23.5 \%)$ & $<3.0-30.0$ \\
\hline Fried Rice Vermicelli & $100-150$ & $94(29 \%)$ & $16(17.0 \%)$ & $<3.0-350.0$ & $2(11.8 \%)$ & $<3.0-11.0$ \\
\hline Total & & $329(100 \%)$ & $66(100 \%)$ & & $17(100 \%)$ & \\
\hline
\end{tabular}

cause of foodborne illness outbreaks (Lues and van Tonder, 2007). The inconsistent practice of food hygiene and sanitation by the food handlers increase the possibility of contaminations of the pathogens in the food. According to Lee et al. (2017), most food handlers had low performance in maintaining hygienic hands although it was reported that they had a moderate level of food safety knowledge with a good attitude and, selfreported practices. Jensen et al. (2017) conducted a study on the quantification of bacterial cross-contamination rates between fresh-cut produce and hands and the study concluded that transfer rates are higher from hands to food while transfer rates from food to hands were approximately $1 \%$. The indirect cross-contamination of pathogens from hands to food could be due to that the pathogens are being provided with the source of nutrients from food which favours their growth and attachment (New, Wong, Usha et al., 2017).

The high detection of generic E. coli might be due to its high presence in raw vegetables that is in contact with soil or contaminated water and used as a part of the ingredient in RTE food. Most RTE food was observed to have some raw vegetable garnishing placed on the food which presumably became the vehicle of contamination for E. coli. Pathogenic E. coli O157: H7 is frequently found in soil (Ibekwe et al., 2014) and water sources if contaminated with faeces from infected humans or animals. The presence of $E$. coli on food indicates faecal contamination, which can lead to the possible presence of other harmful microorganisms, viral or helminthic of protozoal parasites (Jay, 1997). It was reported that $E$. coli can adhere to roots from contaminated soil and/or water, and subsequently travel through the plant to the leaf tissue (Cooley et al., 2003; Bernstein et al., 2007). The occurrence of Salmonella spp. on leafy green produce was also reported via the irrigation of poor quality water, but the counts were reported lower than generic E. coli (Benjamin et al., 2013) which possibly explained why the presence of generic E. coli was higher than Salmonella spp. in this study. In addition, the physical structure of the raw vegetables was probably not affected by the microwave heating, which also did not affect the pathogens present. It was reported that the loss factor, $\varepsilon "$, which is translated to heat in microwave heating for fruits and vegetables were low at high frequencies (Sosa-Morales et al., 2010).

The total number of $S$. enterica serovars (Typhimurium and Enteritidis) detected were slightly higher than STEC O157 which is in accordance with the outbreaks reported concerning with the microwave oven were caused by $S$. enterica serovars. The MPN concentrations reported for both $S$. enterica serovars and STEC could cause an infection. Hara-Kudo and Takatori (2011) reported on the ingestion dose of foodborne pathogens associated with infections were as low as 81 MPN/g for $S$. enterica serovar Enteritidis and $<108$ MPN/g for STEC O157 in outbreaks occurring in Japan between 2004 to 2006. In fact, Salmonella was reported to be able to cause severe adverse health effects at low infectious doses of $0.042-0.427 \mathrm{MPN} / \mathrm{g}$ in a toasted cereal outbreak reported by Wang et al. (2015). Thus, the reported MPN concentrations in this study were well above the ingestion dose associated with infections which suggested the consumption of the contaminated RTE food with survived pathogens after microwave heating will cause foodborne illness especially for Salmonella as few cells are sufficient to colonize the lower gastrointestinal tract (Waterman and Small, 1998) and further, Salmonella may gain protection from the fats in some food products against the harsh stomach acidic condition, increasing the likelihood of illness despite the low number of viable organisms consumed (D'Aoust, 1977; D'Aoust and Maurer, 2007).

The survivability of pathogens was most presumably due to the uneven heating distribution - the major issue of microwave heating that is affected by many factors such as food composition, temperature, ionic conduction and water availability. According to Fakhouri and Ramaswamy (1993), microwave heating is 'fooddependent' unlike conventional heating. Starch and protein foods have minimal effect with microwaves due to its nature non-polar charges of the molecules which indicated no heating will occur when being subjected to microwaves (Chandrasekaran et al., 2013). The hydroxyl 
groups in starch and protein behave similarly, only that the ability to follow the rotation of the electromagnetic field was hindered due to high shear environment (Chaplin, 2015) and thus, reducing the ability to extract energy from the field (Feng et al., 2012). Fat, on the other hand, improves heating rate when subject to microwaves due to the lower specific heat which gives rise to the rapid heat (Chaplin, 2015).

Moreover, the current temperature of the food affects the microwave heating in a complex way. According to Venkatesh and Raghavan (2004) and Feng et al. (2012), the complexity of the relationship between temperature requires the need to understand the dielectric dispersion of the water molecules present in food. Meanwhile, the influence of ionic conduction is always positive when temperature increases (Feng et al., 2012) as the salts decreases the natural structuring of water and reducing its dipole-dipole moments ability. Depending on the water and the content of it in the food in relative to the temperature, the microwave heating will be affected either increase or decrease.

The presence of salt in foods contributes to the ionic conduction and microwave heating at high frequencies of domestic microwave ovens $(2.45 \mathrm{GHz})$ is not favourable as the ions will not be able to respond quicker to produce frictional force in contrast to lower frequencies of microwave ovens (Chaplin, 2005). Otherwise, foods that are high in salt will become better microwave absorber and gets heated rapidly. Water availability is unquestionably the biggest factor to microwave heating as water molecules are the major contributors to dielectric heating. This depends on free water and bound water available in the food product. More than $70 \%$ of the free water dispersion contributes to dielectric heating (Feng et al., 2012).

All in all, the microwave heating affected by the factors above causes the uneven heating distribution in microwave heated food. The factors affecting the microwave heating are relative to one another. This led to the presence of cold spots in food and if bacteria were present within the zone, the bacteria could survive through the microwave heating. The center temperature measured from the samples (Figure 4) evidently showed the fluctuation temperature of the food after microwave heating, inferring the uneven heating distribution. Most samples could not reach the safe temperature minimum requirement $\left(75^{\circ} \mathrm{C}\right)$ with only approximately $4.0 \%$ $(13 / 329)$ from the total samples achieved more than $75^{\circ}$ C. Most of the samples ranged between $60-70^{\circ} \mathrm{C}$ at the center temperature. Salmonella was reportedly destroyed at cooking temperatures above $65^{\circ} \mathrm{C}$ while $E$. coli will not survive above $71^{\circ} \mathrm{C}$. The center temperatures of the food samples were practically within the range of the pathogens' survival. This added more concerns to microbiological safety of the RTE foods.

A recent obscure research reported that some strains of non-pathogenic E. coli were heat resistant. However, the unbeknown risk may present as some pathogenic strains of E. coli could be heat resistance (Flynn, 2016) which supports the findings of this study and amplifying the risk. This study had indicated the possibility when seventeen strains of STEC O157 were recovered from microwave heated food, but this was yet to be confirmed as the strains of STEC O157 survivability could be linked to the non-uniform temperature distribution of the microwave heating. Salmonella was reported able to have increased thermal tolerance in foods with low water activity combined with high-fat content (Werber et al., 2005). All the samples had a substantial amount of fat but had high water activity which led to the lower outcomes of Salmonella in this study. It could also partially be due to the absence or low initial number of Salmonella in the types of food sampled although Salmonella can be present in any foods when contaminated (Wagner, 2008) due to its versatility.

The survivability of the pathogens could also depend on the food matrix. Clumping of bacteria within the food matrix could limit the inactivation via microwave heating due to the low penetrating depth of the microwaves at high frequency. If the food samples were contaminated and contained high moisture which supports the growth of the bacteria in the food, the available moisture will contribute to higher dielectric heating to inactivate the pathogens, but the effectiveness of the inactivation will have to depend on the microwave heating time.

Microwave heating time is another factor that contributes to the survivability of the pathogens. It was observed that most microwave ovens available in convenience stores and restaurants are equipped with time turners, allowing consumers to turn the time to reheat the food according to their likings. Further, consumers might have a misconception towards the microwaves: having the thought that microwaves are radioactive waves that can kill the pathogens at the same time the food is being reheated quickly. This perception led them to reheat the food as fast as possible or stop the process whenever the food container was warm enough. In fact, there are no guidelines or safety regulations in which determined how long should the food be heated to ensure that microwave heated food is microbiologically safe. Consumers' lack of knowledge on the microwave oven should also be considered. The cause of the reported outbreaks was mostly due to consumers' lack of 


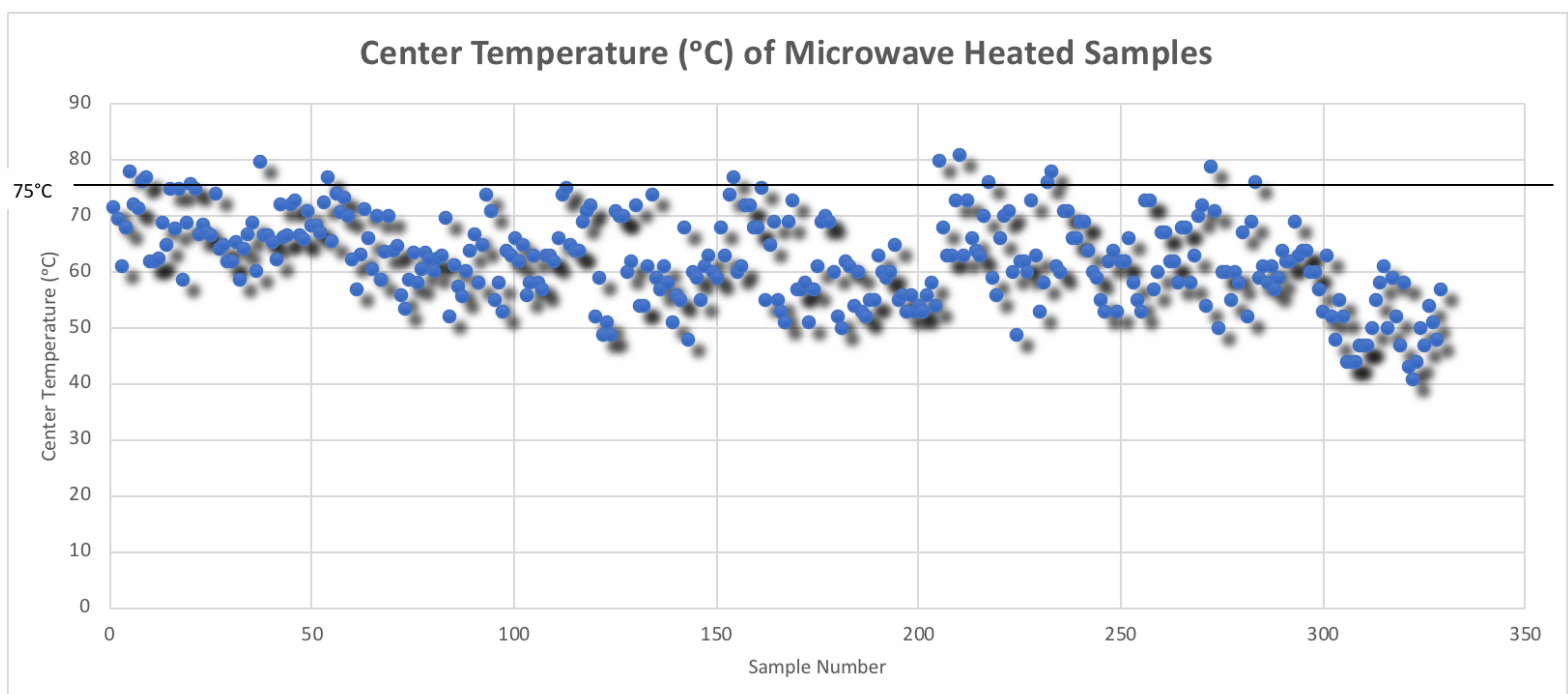

Figure 4. The center temperatures of the microwave heated RTE foods.

Table 5. Risk estimates of consumption of Salmonella and STEC O157 in microwave heated RTE foods

\begin{tabular}{|c|c|c|c|c|c|c|}
\hline & \multicolumn{3}{|c|}{ Salmonella } & \multicolumn{3}{|c|}{ STEC O157 } \\
\hline & Rice & Noodles & Rice Vermicelli & Rice & Noodles & Rice Vermicelli \\
\hline \multicolumn{7}{|c|}{ Concentration $(\log \mathrm{MPN} / \mathrm{g})$} \\
\hline 5th Percentile & 0.791 & 1.011 & 0.851 & 0.820 & 1.087 & 0.907 \\
\hline 25th Percentile & 1.236 & 1.477 & 1.197 & 1.150 & 1.550 & 0.937 \\
\hline 50th Percentile & 1.677 & 1.858 & 1.487 & 1.420 & 1.906 & 0.962 \\
\hline 75th Percentile & 2.181 & 2.236 & 1.778 & 1.704 & 2.242 & 0.985 \\
\hline 95th Percentile & 2.895 & 2.688 & 2.135 & 2.052 & 2.620 & 1.013 \\
\hline Average & 1.738 & 1.855 & 1.488 & 1.428 & 1.887 & 0.961 \\
\hline Serving Size (g) & $289.68 \pm 2.07$ & $66.36 \pm 1.32$ & $66.56 \pm 1.35$ & $289.68 \pm 2.07$ & $66.36 \pm 1.32$ & $66.56 \pm 1.35$ \\
\hline $\begin{array}{l}\text { Total Exposure in } \\
\text { Food }\end{array}$ & $1.58 \times 10^{4}$ & $4 . .75 \times 10^{3}$ & $2.05 \times 10^{3}$ & $7.75 \times 10^{3}$ & $5.11 \times 10^{3}$ & $6.08 \times 10^{2}$ \\
\hline $\begin{array}{l}\text { Probability of Illness } \\
\text { per serving }\end{array}$ & 0.443 & 0.262 & 0.154 & 0.8156 & 0.6718 & 0.1242 \\
\hline Rate per 100,000 & 0.4292 & 0.2782 & 0.1772 & 0.7525 & 0.6463 & 0.1246 \\
\hline
\end{tabular}

knowledge on microwave oven, e.g. usage, principles, and food safety as well as their confusion and ignorance on the microwave instructions given by the food manufacturers. All these eventually contributed to the pathogens' survival in the food, if present, and grow to a hazardous level which could cause foodborne illness to those exposed.

Foodborne illness is considered as a global economic burden as the impact could cause many to be hospitalized and deaths if drastic actions are not taken and great expenditure on the health care costs. The distribution of the food globally exacerbates the matter by disseminating the biohazard and preventing fast control measures, making it more difficult to intervene. It is no exception to this study as it was observed the RTE food were supplied by different suppliers to the convenience store and the supplier has many other similar customers to supply to. Food travels locally and globally, and hence, this amplifies the risk, having more people exposed.

The risk of exposure to the survived pathogens through microwave heating is estimated and summarized in Table 5. As observed from Table 5, the concentration of the Salmonella was at an average of $1.738 \mathrm{log}$ MPN/g, $1.855 \log \mathrm{MPN} / \mathrm{g}$ and $1.4882 \log \mathrm{MPN} / \mathrm{g}$ for rice, noodles and rice vermicelli respectively, while the concentration of STEC $\mathrm{O} 157$ was at an average of 1.43 $\log \mathrm{MPN} / \mathrm{g}, 1.887 \log \mathrm{MPN} / \mathrm{g}$, and $0.961 \log \mathrm{MPN} / \mathrm{g}$ for rice, noodles and rice vermicelli respectively. The concentration of the pathogen and the serving size of the food determined the total exposure of the pathogen in the food and thus, the higher the concentration and serving size of the food, the higher the exposure of the pathogen to humans. The probability of illness and the rates per 100,000 iterations estimated were significant to indicate a high chance of contracting foodborne illness. From Table 5, it was noted that STEC O157 simulated a higher impact of foodborne illness occurrences despite some concentrations of the pathogens were lower compared to Salmonella. This was because STEC O157 was simulated using the exponential dose-response model which assumed that one organism is capable of producing an infection. In comparison to Salmonella which was simulated using the Beta-Poisson Model, the model assumed that non-constant survival and infection 
probabilities caused by the organism.

The rate of foodborne illness was estimated to be 0.4292 (130 cases), 0.2782 (84 cases) and 0.1772 (54 cases) for rice, noodles, and rice vermicelli respectively for Salmonella. While for STEC O157, the rate of foodborne illness was estimated to be 0.7525 (228 cases), 0.6463 (196 cases) and 0.1246 (38 cases) for rice, noodles, and rice vermicelli respectively. Based on the previous epidemiological data on non-typhoidal salmonellosis (NTS) (Food Safety News, 2014; Astro Awani, 2014) in Malaysia, the predicted foodborne illness cases for Salmonella were in agreement for RTE foods. On the other hand, there was no reported epidemiological data of the similar type of food for STEC O157 in the Southeast Asia that can be compared to the current study. As Malaysia reports incidence rate as an overall foodborne poisoning, it is difficult to distinguish which pathogen contributed more cases and vice versa. The predicted cases were assumed to contribute at least 0.3 to $1.6 \%$ of the incidence rates of foodborne poisoning in Malaysia based on the available data in 2015 summarized by Ministry of Health, Malaysia (2016). It should be noted that although the predictions were in agreement, it should not be assumed as reliable as it is easy to adjust assumptions and input settings in the risk assessment model. Hence, the inputs and outputs of each unit operation and pathogen event in the risk assessment should be validated (Oscar, 2004).

Through the simulation, the high concentration of the survived pathogens in the food was the main contributing factor to such high risk estimates. This is probably due to the high initial microbial load present in the RTE food that was ineffectively inactivated during microwave heating. On the other hand, RTE food prepared for sale was not directly consumed and held for display at a certain time in the convenience store before sold. A longer holding time will allow the pathogens to grow to a hazardous level whereby microwave heating will not be able to reduce the load to a safe level, especially fastidious pathogens such as Salmonella and $E$. coli. And with the lack of consumer's knowledge on the microwave oven, the surviving pathogens present a risk to consumers as they are metabolically active to infect and intoxicate.

The simulation model could be refined with the addition of more critical data to display the real scenario of the exposure route of the pathogens, particularly the dose-response model. The dose response model depends on the susceptibility of a person to be affected towards the dose administered. Having an optimized doseresponse model allows greater flexibility and a wider range of understanding in the estimated risk. Minimal to none dose response model studies on the Asian demographic were reported which is a data limitation to our study. It is noted that consumer behavior on habit and consumption patterns are critical to obtaining a good estimate risk (Barraj and Peterson, 2004). As our study did not include any consumption patterns in which we assumed that consumers will directly consume the food after being heated. Some consumers may have heated their food and brought it back to their homes or offices to consume. That will provide a certain holding time to the survived pathogens to grow which will result in different concentrations. These data gaps are yet to be confirmed and the risk could be underestimated or overestimated. Nonetheless, the risk assessment could serve a vague purpose in suggesting interventions. By refining the model, the sensitivity of the model will be increased, and the direct risk mitigations could be carried out.

\section{Conclusion}

The prevalence of pathogens survival and the risk assessment conducted had evaluated the possible risks of exposure to pathogens from microwave heated foods as their vehicle of contamination. The identified risk factors that contributed to the survival of the pathogens were the uneven microwave heating distribution, the microwave heating time and consumers' lack of knowledge on the microwave oven and food safety. Microbial safety concerns of microwave heated food should be put into the spotlight as the relative importance is not well understood by consumers. Food safety guidelines on the microwave oven should be proposed to alert and educate the consumers on microwave oven and the safety of microwaved food. Besides that, practicing proper hygiene and sanitation by food handlers and taking food safety measures, foodborne illness could be controlled, and thus reduce the economic burden imposed by foodborne illness and preserve the public health.

\section{Conflict of Interest}

The authors declare no conflict of interest.

\section{Acknowledgement}

Research fund was sponsored by Fundamental Research Grant Projects (FRGS/1/2014/SG05/ UPM/01/2) from the Ministry of Education, Malaysia and in part by the Universiti Putra Malaysia Grant GPIPS 2015 (GP-IPS/2015/9466100).

\section{References}

Astro Awani. (2014). 5-year-old boy's death linked to Salmonella bacteria. Retrieved May 17, 2017 from Astro Awani Website: http://english.astroawani.com/ 
malaysia-news/5-year-oldboys-death-linkedsalmonella-bacteria-31233

Bai, J., Shi, X. and Nagaraja, T.G. (2010). A multiplex PCR procedure for the detection of six major virulence genes in Escherichia coli O157: H7. Journal of Microbiological Methods, 82, 85-89. https://doi.org/10.1016/j.mimet.2010.05.003

Barraj, L.M. and Petersen, B.J. (2004). Food consumption data in microbiological risk assessment. Journal of Food Protection, 67, 19721976. https://doi.org/10.4315/0362-028X-67.9.1972

Benjamin, L., Atwill, E.R., Jay-Russell, M., Cooley, M., Carychao, D., Gorski, L. and Mandrell, R.E. (2013). Occurrence of generic Escherichia coli, E. coli $\mathrm{O} 157$ and Salmonella spp. in water and sediment from leafy green produce farms and streams on the Central California coast. International Journal of Food Microbiology, 165(1), 65-76. https:// doi.org/10.1016/j.ijfoodmicro.2013.04.003

Bernstein, N., Sela, S. and Neder-Lavon, S. (2007). Assessment of contamination potential of lettuce by Salmonella enterica serovar Newport added to the plant growing medium. Journal of Food Protection, 70, 1717-1722. https://doi.org/10.4315/0362-028X70.7.1717

Bertrand, R. and Roig, B. (2007). Evaluation of enrichment-free PCR-based detection on the $r f b E$ gene of Escherichia coli O157- application to municipal wastewater. Water Resources, 41, 12801286. https://doi.org/10.1016/j.watres.2006.11.027

Blodgett, R. (2006). Most probable number form serial dilutions. Bacteriological analytical manual online. Gaithersburg: AOAC International. Retrieved September 14, 2015 from FDA website: https:// www.fda.gov/food/foodscienceresearch/

laboratorymethods/ucm109656.htm

Campanone, L.A. and Zaritzky, N.E. (2005). Mathematical analysis of microwave heating process. Journal of Food Engineering, 69(3), 359368. https://doi.org/10.1016/j.jfoodeng.2004.08.027

Chandrasekaran, S., Ramanathan, S. and Basak, T. (2013). Microwave food processing - A review. Food Research International, 52, 243 - 261. https:// doi.org/10.1016/j.foodres.2013.02.033

Chaplin, M. (2015). Water and microwaves. Retrieved January 30, 2017 from website: http:// www1.1sbu.ac.uk/water/microwave water.html

Cooley, M.B., Miller, W.G. and Mandrell, R.E. (2003). Colonization of Arabidopsis thaliana with Salmonella enterica and enterohemorrhagic Escherichia coli O157:H7 and competition by Enterobacter asburiae. Applied and Environmental
Microbiology, 69, 4915-4926. https:// doi.org/10.1128/AEM.69.8.4915-4926.2003

Cornick, N.A. and Helgerson, F.A. (2004). Transmission and infectious dose of Escherichia coli O157: $\mathrm{H} 7$ in swine. Applied Environment Microbiology, 70(9), 5331-5335. https://doi.org/10.1128/AEM.70.9.53315335.2004

Daniel, W.W. (1999). Biostatistics: a foundation for analysis in the health sciences. 7th ed. New York: John Wiley and Sons.

D'Aoust, J.-Y. (1977). Salmonella and the chocolate industry: a review. Journal of Food Protection, 40 (10), 718-727. https://doi.org/10.4315/0362-028X40.10 .718

D'Aoust, J.-Y. and Maurer, J. (2007). Salmonella species. In Doyle, M.P. and Beuchat, L.R. (Eds.) Food microbiology: Fundamentals and Frontiers. 3rd ed., p.187-236. Washington DC: ASM Press. https:// doi.org/10.1128/9781555815912.ch10

de Freitas, C.G., Santana, A.O., da Silva, P.H.C., Goncalves, V.S.P., Barros, M.D.A.F., Torres, F.A.G., Murata, L.S. and Perecmanis, S. (2010). PCR multiplex for detection of Salmonella Enteritidis, Typhi, and Typhimurium and occurrence in poultry meat. International Journal of Food Microbiology 139: 15-22. https://doi.org/10.1016/ j.ijfoodmicro.2010.02.007

Decareau, R.V. (1985). Microwaves in the food processing industry. Orlando: Academic Press Inc.

Decareau, R.V. and Peterson, R.A. (1986). Microwave processing and engineering. Chichester, England: Ellis Horwood Publishers

Evans, A.S. and Brachman, P.S. (1998). Bacterial Infections of humans: epidemiology and control. $3^{\text {rd }}$ ed. New York: Kluwer Academic. https:// doi.org/10.1007/978-1-4615-5327-4

Fagan, P.K., Hornitzky, M.A., Bettelheim, K.A. and Djordjevic, S.P. (1999). Detection of Shiga like toxin (stx1 and stx2), intimin (eaeA), and enterohemorrhagic Escherichia coli (EHEC) hemolysin (EHEC hlyA) genes in animal feces by multiplex PCR. Applied and Environmental Microbiology, 65(2), 868-872

Fakhouri, M.O. and Ramaswamy, H.S. (1993). Temperature uniformity of microwave heated foods as influenced by product type and composition. Food Research International, 26, 89-95. https:// doi.org/10.1016/0963-9969(93)90062-N

Feng, H., Yin, Y. and Tang, J. (2012). Microwave drying of food and agricultural materials: basics and heat and mass transfer modeling. Food Engineering Reviews. https://doi.org/10.1007/s12393-012-9048-x 
Flynn, D. (2016). Research finds some E. coli survive cooking temperatures. Retrieved March 1, 2017 from Food Safety News website: http:// www.foodsafetynews.com/2016/06/127257/ \#.WLae62997Dd.

Food Safety News. (2014). 158 students in Malaysia sickened by foodborne Illness. Retrieved June 24, 2016 from Food Safety News website: http:// www.foodsafetynews.com/2014/02/158-students-inmalaysia-sick-with-food-poisoning/\#.V2yng_197Dc.

Fu, Y-C. (2006). In Hui, Y.H. (Ed.) Handbook of food science, technology and engineering. Vol. 3. Boca Raton: CRC Taylor and Francis Group.

Geedipalli, S.S.R., Rakesh, V. and Datta, A.K. (2007). Modeling the heating uniformity contributed by a rotating turntable in microwave ovens. Journal of Food Engineering, 82, 359-368. https:// doi.org/10.1016/j.jfoodeng.2007.02.050

Gessner B.D. and Beller, M. (1994). Protective effect of conventional cooking versus use of microwave ovens in an outbreak of salmonellosis. American Journal of Epidemiology, 139, 903-909. https:// doi.org/10.1093/oxfordjournals.aje.a117096

Gunasekaran, S. and Yang, H. (2007). Effect of experimental parameters on temperature distribution during continuous and pulsed microwave heating. Journal of Food Engineering, 78(4), 1452-1456. https://doi.org/10.1016/j.jfoodeng.2006.01.017

Hara-Kudo, Y. and Takatori, K. (2011). Contamination level and ingestion dose of foodborne pathogens associated with infections. Epidemiology and Infection, 139, 1505-1510. https://doi.org/10.1017/ S095026881000292X

Ho, Y.C. and Yam, K.L. (1992). Effect of metal shielding on microwave heating uniformity of a cylindrical food model. Journal of Food Processing and Preservation, 16(5), 337-359. https:// doi.org/10.1111/j.1745-4549.1992.tb00214.x

Hoogenboom, R., Wilms, T.F.A., Erdmenger, T. and Schubert, U.S. (2009). Microwave Assisted Chemistry: a closer look at heating efficiency. Australian Journal of Chemistry, 62, 236-243. https://doi.org/10.1071/CH08503

Ibekwe, A.M., Ma, J., Crowley, D.E., Yang, C.H., Johnson, A.M., Petrossian, T.C. and Lum, P.Y. (2014). Topological data analysis of Escherichia coli O157: H7 and non-O157 survival in soils. Frontiers in Cellular and Infection Microbiology, 4, 122. https://doi.org/10.3389/fcimb.2014.00122

Jay, J.M. (1997). Modern food microbiology. 5th ed, p. 17-19. New York: Chapman and Hall.

Jensen, D.A., Danyluk, M.D., Harris, L.J. and Schaffner,
D.W. (2017). Quantifying bacterial crosscontamination rates between fresh-cut produce and hands. Journal of Food Protection, 80(2), 213-219. https://doi.org/10.4315/0362-028X.JFP-16-240

Larsen, L. (2013). Farm Rich E. coli Outbreak Issues: Label Confusion and Microwave Ovens. Retrieved on October 23, 2016 from: https:// foodpoisoningbulletin.com/2013/farm-rich-e-colioutbreak-issues-label-confusion-and-microwaveovens/

Lee, H.K., Halim, H.A., Thong, K.L. and Chai, L.C. (2017). Assessment of food safety knowledge, attitude, self-reported practices, and microbiological hand hygiene of food handlers. International Journal of Environmental Research and Public Health, 14, 55. https://doi.org/10.3390/ijerph14010055

Lues, J.F.R. and van Tonder, I. (2007). The occurrence of indicator bacteria on hands and aprons of food handlers in the delicatessen sections of a retail group. Food Control, 18(4), 326-332. https:// doi.org/10.1016/j.foodcont.2005.10.010

Manickavasagan, A., Jayas, D.S. and White, N.D.G. (2006). Non-uniformity of surface temperatures of grain after microwave treatment in an industrial microwave dryer. Drying Technology 24(12): 15591567

Meredith, R.J. 1998. Engineers' handbook of industrial microwave heating. London: Institution of Electrical Engineering

Meyer, S., Smith, K., Sowadsky, R., Henao, O., Nguyen T., Austin, J. and Mody, R. (2008). Multistate outbreak of Salmonella infections associated with frozen pot pies - United States, 2007. Morbidity and Mortality Weekly Report (MMWR), 57(47), 12771280

Ministry of Health, Malaysia. (2013). Food consumption statistics of Malaysia 2003. Malaysia: Family Health Development Division, Food Safety and Quality Division, Department of Public Health, Ministry of Health Malaysia.

Ministry of Health, Malaysia. (2016). Health facts. Retrieved October 17, 2017 from Ministry of Health Malaysia website: http://www.moh.gov.my/images/ gallery/publications/KKM\%20HEALTH\% 20FACTS\%202016.pdf.

Mullin, J. and Bows, J. (1993). Temperature measurements during microwave cooking. Food Additives and Contaminants, 10(6), 663-672.

Naing, L., Winn, T. and Rusli, B.N. (2006). Practical issues in calculating the sample size for prevalence studies. Archives of Orofacial Sciences, 1, 9-14.

New, C.Y., Thung, T.Y., Premarathne, J.M.K.J.K., 
Russly, A.R., Abdulkarim, S.M. and Son, R. (2017). Microwave oven safety: a food safety consumer survey in Malaysia. Food Control, 80, 420-427. https://doi.org/10.1016/j.foodcont.2017.05.024.

New, C.Y., Wong, C.Y., Usha, M., Ubong, A., Nakaguchi, Y., Nishibuchi, M. and Son, R. (2017). Level of Campylobacter jejuni from naturally contaminated chicken liver and chicken legs in various task: a cross contamination study. Food Research, 1(2), 33-37. https://doi.org/10.26656/ fr.2017.2.010

Oliviera, M.E.C. and Franca, A.S. (2002). Microwave heating of foodstuffs. Journal of Food Engineering, 53(4), 347-359. https://doi.org/10.1016/S0260-8774 (01)00176-5

Oscar, T.P. (2004). A quantitative risk assessment model for Salmonella and whole chickens. International Journal of Food Microbiology, 93, 231-247. https:// doi.org/10.1016/j.ijfoodmicro.2003.12.002

Pourhoseingholi, M.A., Vahedi, M. and Rahimzadeh, M. (2013). Sample size calculation in medical studies. Gastroenterology and Hepatology from Bed to Bench, 6(1), 14-17.

Puligundia, P., Abdullah, S.A, Choi, W., Jun, S., Oh, S.E. and Ko, S. (2013). Potentials of microwave heating technology for select food processing applications - a brief overview and update. Journal of Food Processing and Technology, 4(11), 278.

Rounds, J., Lane, T., Kessler, B. and Hausman, L. (2013). Multistate outbreak of Salmonella Chester infections associated with frozen meals - 18 States, 2010. Morbidity and Mortality Weekly Report (MMWR), 62(48), 979-982.

Ryynanen, S. and Ohlsson, T. (1996). Microwave heating uniformity of ready meals as affected by placement, composition, and geometry. Journal of Food Science 61(3): 620-624. https:// doi.org/10.1111/j.1365-2621.1996.tb13171.x

Sabat, G., Rose, P., Hickey, W.J. and Harkin, J.M. (2000). Selective and sensitive method for PCR amplification of Escherichia coli 16S rRNA genes in soil. Applied and Environmental Microbiology, 66 (2), 844-849. https://doi.org/10.1128/AEM.66.2.844849.2000

Salazar-Gonzalez, C., San Martin-Gonzalez, M.F., Lopez -Malo, A. and Sosa-Morales, M.E. (2012). Recent studies related to microwave processing of fluid foods. Food Bioprocess and Technology, 5, 31-46. https://doi.org/10.1007/s11947-011-0639-y

Smith, K.E., Medus, C., Meyer, S.D., Boxrud, D.J., Leano, F., Hedberg, C.W., Elfering, K., Braymen, C., Bender, J.B. and Danilla, R.N. (2008). Outbreaks of salmonellosis in Minnesota (1998 through 2006) associated with frozen, microwaveable, breaded, stuffed chicken products. Journal of Food Protection, 71(10), 2153-2160. https:// doi.org/10.4315/0362-028X-71.10.2153

Sosa-Morales, M.E., Tiwari, G., Wang, S., Tang, J., Lopez-Malo, A. and Garcia, H.S. (2009). Dielectric heating as a potential post-harvest treatment of disinfesting mangoes I: relation between dielectric properties and ripening. Biosystems Engineering, 103, 297-303. https://doi.org/10.1016/ j.biosystemseng.2009.02.015

Stegniy, B., Gerilovych, A., Arefyev, V., Glebova, K. and Potkonjak, A. (2014). A method for detecting and typing of Salmonella by multiplex PCR. Arhiv, Veterinarske Medicine, 7(2), 47-56.

Tang, J.Y.H., Mohamad Ghazali, F., Saleha, A.A., Nishibuchi, M. and Son, R. (2009). Comparison of thermophilic Campylobacter spp. occurrence in two types of retain chicken samples. International Food Research Journal, 16, 277-288.

United States Department of Agriculture (USDA) Food Safety and Inspection Service (FSIS). (2011). Food safety information: microwave ovens and food safety. Retrieved August 24, 2014 from USDA FSIS Website: www.fsis.usda.gov/shared/PDF/ Microwave_Ovens_and_Food_Safety.pdf

Vadivambal, R. and Jayas, D.S. (2010). Non-uniform temperature distribution during microwave heating of food materials - a review. Food and Bioprocess Technology, 3(2), 161-171. https://doi.org/10.1007/ s11947-008-0136-0

Venkatesh, M.S. and Raghavan, G.S.V. (2004). An overview of microwave processing and dielectric properties of agri-food materials. Biosystems Engineering, 88(1), 1-18. https://doi.org/10.1016/ j.biosystemseng.2004.01.007

Wagner, A.B. (2008). Bacterial food poisoning. food technology and processing. Retrieved March 1, 2017 from website: http://aggie-horticulture.tamu.edu/ food-technology/bacterial-food-poisoning/

Wang, H., Gill, V.S., Cheng, C-M., Gonzalez-Escalona, N., Irvin, K.A., Zheng, J., Bell, R.J., Jacobson, A.P. and Hammack, T.S. (2015). Evaluation and comparison of rapid methods for the detection of Salmonella in naturally contaminated pine nuts using different pre-enrichment media. Food Microbiology, 46, 58-65. https://doi.org/10.1016/j.fm.2014.06.028

Wang, L., Rothemund, D., Curd, H. and Reeves, P.R. (2000). Sequence diversity of the Escherichia coli H7 fliC genes: implication for a DNA-based typing scheme for E. coli O157: H7. Journal of Clinical 
Microbiology, 38, 1786-1790.

Waterman, S.C. and Small, P.L.C. (1998). Acid-sensitive enteric pathogens are protected from killing under extremely acidic conditions of $\mathrm{pH} 2.5$ when they are inoculated onto certain solid food sources. Applied and Environmental Microbiology, 64(10), 38823886

Werber, D., Dreesman, J., Feil, F., Van Treeck, U., Fell, G., Ethelberg, S., Hauri, A.M., Roggentin, P., Prager, R., Fisher, I.S.T. Behnke, S.C., Bartelt, E., Weise, E., Ellis, A., Siitonen, A., Andersson, Y., Tschape, H., Kramer, M.H. and Ammon, A. (2005). International outbreak of Salmonella Oranienburg due to German chocolate. BMC Infectious Diseases, 5, 7. https:// doi.org/10.1186/1471-2334-5-7

World Health Organization (WHO). 2002. Risk assessments for Salmonella in eggs and broiler chickens: interpretative summary (microbiological risk assessment series) US: WHO.

Zhang, M., Tang, J., Mujumdar, A.S. and Wang, S. (2006). Trends in microwave-related drying of fruits and vegetables. Trends in Food Science and Technology, 17, 524-534. https://doi.org/10.1016/ j.tifs.2006.04.011. 